In 1863 the Abbé L. Bourgeois, with the Abbé Delaunay and M. Bouvet, found some worked flints at the outcrop of some freshwater beds of the lower part of the Calcaire de Beauce, above the bank of the stream of Thenay, near Pontlevoy (Loir-et-Cher), France; and in 1869, to certify their position, MM. Bourgeois and Delaunay had a pit dug on the top of the hill, at about a hundred mètres within the edge of the plateau above the valley, and believed that they discovered several well-characterized flint instruments, at a depth of six mètres, in the same marly beds of the Beance Limestone that crop out on the hill-side below. See Bulletin Soc. Géol. France, ser. 2, vol. xx. 1863, pp. 535-542 ; vol. xxvi. 1869, pp. 901-902 ; vol. xxvii. 1870, pp. 519-520 (M. Raulin). Some geologists and archæologists have not accepted M. Bourgeois' interpretation of the facts, and others have ignored it; but there still remains the possibility of this Miocene occurrence of man-worked flints. This is strengthened by the finding of such relics in the Miocene of Burma; nor need we hesitate to allow that Man, as well as such Miocene animals as the Hippotherium (Hipparion), could, within a limited period, spread over the Asiatico-European continent, so as to constitute a real contemporaneity, and not merely a homo= taxis, of the fossiliferous strata in that far-back stage of Geological History.

T. RuPERT Jones.

\title{
CORRESPONDEITOF.
}

\section{AN ERECT TREE IN THE COAL-MEASURES.}

SrR,-My brother-in-law, Mr. J. C. Brierley, of Rochdale, has sent me some photographs of a recent discovery there, which I think you might like to record in the Geological Magazine. My friend Mr. Platt, of Rochdale, may possibly describe it at greater length. It is that of a very perfect internal cast of an erect Sigillarian trunk rooted in the ground and rising to the unusual beight of more than six feet, with a circumference at the base of about the same, and of four feet at its present summit. As now exposed there are three main roots from the trunk, each of which bifurcates. Near the base of the trunk the bark has been preserved in a carbonized form. The tree stands in a bed of Carboniferous shale in the Lower Coal-measures, which forms an insular mass in the bottom of the valley of the Roach and is topped by Boulder-clay. Apart from other interesting circumstances, the trunk is clearly in situ, and it affords good evidence of the very rapid accumulation under certain conditions of some of the primary rocks. It cannot be doubted that the shales which enclose it must have been deposited very rapidly, or else the trunk itself would have weathered away. It is also a proof that whatever deposited the Bonlder-clay in the valley of the Roach, it could not have been an instrument of very active erosion, or such masses of soft shale as this, enclosing a perpendicular tree-trunk, would have been swept away. (See illustration on page 528.)

HenRy H. Howorth. 